\title{
DESTRUINDO ESTÁTUAS: O INCÊNDIO NO MONUMENTO A BORBA GATO E A RELEVÂNCIA DA MEMÓRIA PELO OLHAR DOS OPRIMIDOS
}

\author{
Lara Ferreira Lorenzoni* \\ Raoni Vieira Gomes**
}

RESUMO: A memória é construção da identidade de um povo, fenômeno de caráter eminentemente político. Traçando o problema da identificação afetiva com o vencedor, coloca-se aqui o incêndio na estátua de Manuel de Borba Gato em perspectiva, sob a tese do necessário acerto de contas com o passado pelo olhar dos oprimidos. Assim, faz-se o exame do evento ocorrido no Brasil dentro do contexto mais amplo da milenar luta por identidade, reconhecimento e memória, que, na historiografia benjaminiana, deve se dar nos termos daquilo o que foi deixado para trás na passarela dos fatos pela marcha imponente dos vencedores.

Palavras-chave: memória; Walter Benjamin; história; estátuas; Borba Gato.

\section{DESTROYING STATUES: THE FIRE AT THE BORBA GATO MONUMENT AND THE RELEVANCE OF MEMORY THROUGH THE EYES OF THE OPPRESSED}

ABSTRACT: Memory is the construction of a people's identity, a political phenomenon. Tracing the problem of affective identification with the winner, the fire at the statue of Manuel de Borba Gato isput into perspective from the point of view of the necessary settling of accounts with the past through the eyes of the oppressed. Thus, we examine the event that occurred in Brazil within the context of the millennial struggle for identity, recognition and memory, which, in Benjaminian historiography, should be given in terms of what was left behind on the catwalk of facts by the march of the victors.

Keywords: memory; Walter Benjamin; history; statues; Borba Gato.

Do rio que tudo arrasta se diz que é violento. Mas ninguém diz violentas as margens que o comprimem.

(Bertolt Brecht).

\section{INTRODUÇÃO}

\footnotetext{
* Doutoranda em Direitos e Garantias Fundamentais pela FDV (bolsista FAPES). Mestre em Direito Processual pela UFES (bolsista FAPES), com ênfase em Direito Processual Penal e História do Direito. Especialista em Direito Penal e Direito Processual Penal. Membro do Grupo de Pesquisa CNPq Teoria Crítica do Constitucionalismo. Advogada. E-mail: laralorenzoni7@gmail.com

** Mestre em Direitos e Garantias Fundamentais pela FDV. Especialista em Ciências Criminais pela FDV. Membro do Grupo de Pesquisa CNPq Teoria Crítica do Constitucionalismo. Membro da Rede de Estudos Benjaminianos. Advogado. E-mail: raonivgomes@gmail.com
} 
A memória é manifestação viva no presente da cultura e herança de um povo. Tendo em mente a plasticidade e a dimensão política que envolve a lembrança e o esquecimento, associada a rupturas históricas significativas, o presente estudo, no rastro da construção teórica de Walter Benjamin, tem por objeto a memória em suas diversas formas de exteriorização, com especial enfoque aos chamados monumentos-relíquia, isto é, homenagens a feitos e figuras históricas específicas. Nesse aspecto, utiliza-se como exemplo privilegiado o ocorrido com a estátua do bandeirante Manuel de Borba Gato na cidade de São Paulo em julho de 2021, ocasião em que manifestantes atearam-lhe fogo e as imagens do monumento em chamas correram o mundo.

Num primeiro momento, demonstrou-se que a memória, enquanto direito fundamental, consiste não apenas no armazenamento de lembranças, mas, sobretudo, na construção e afirmação de identidades - identidade individual ou identidade de um povo. A memória coletiva encontra-se no campo político, com deliberações acerca do que lembrar e do que esquecer, gerando processos de identificação e desidentificação. Caracteriza-se, essencialmente, por uma disputa de poder, e os monumentos históricos estão sujeitos a ser objeto dessa contenda.

Em seguida, tratou-se da identificação afetiva com o vencedor, a partir da filosofia de Walter Benjamin. Na esteira do autor, colocou-se a necessidade de "escovar a história a contrapelo", ou seja, percebê-la da perspectiva dos oprimidos, daqueles que padeceram e não tiveram a oportunidade de contar sua versão. Nessa senda, observa-se que, em todo o mundo, subsistem imensuráveis homenagens a torturadores, saqueadores, escravizadores e assassinos. Para Benjamin, é preciso opor-se a essa tradição, que é um instrumento das classes dominantes.

Por fim, tratou-se do acontecido no Brasil, na cidade de São Paulo, em julho de 2021, ocasião em que a estátua de um conhecido bandeirante foi posta em chamas por manifestantes indignados com a homenagem pública a um escravagista. $\mathrm{O}$ episódio, consumado no rasto do movimento ativista black lives matter, levanta sérias reflexões acerca do que merece ser lembrado frente às pautas políticas engendradas nessa primeira metade do século XXI.

Em se tratando de metodologia de pesquisa, utilizou-se, primeiramente, a investigação bibliográfica como fonte de conceitos essenciais para a construção de um conhecimento capaz de promover uma análise crítica acerca do tema proposto. Para isso, buscaram-se fontes secundárias, especialmente em publicações, como livros e artigos científicos e jornalísticos 
que abarcam a questão. Elegeu-se o método dedutivo, por meio do qual extrai-se uma conclusão lógica a partir de uma premissa maior e de uma premissa menor.

Assim, passa-se ao exame do episódio de julho de 2021 sob o contexto mais amplo da milenar luta por identidade, reconhecimento e memória, que, na historiografia benjaminiana, deve se dar nos termos daquilo o que foi deixado para trás na passarela dos fatos pela marcha imponente dos vencedores.

\section{POR QUE É PRECISO LEMBRAR: DIREITO FUNDAMENTAL À MEMÓRIA E AFIRMAÇÃO DE IDENTIDADE}

A memória, fluxo contínuo de retenção de ideias, impressões, imagens, conhecimentos e experiências, pode se dividir em memória individual e memória coletiva. Enquanto a memória individual traduz-se na aptidão, genética e fisiologicamente determinada, de cada ser humano guardar as experiências vividas, a memória coletiva (ou memória social) consubstancie-se pelo compartilhamento de informações e tradições numa dada sociedade quanto a relatos, documentos, datas, lugares, pessoas e mitos fundadores essenciais para aquela coletividade (DANTAS, 2008, p. 46).

O mito, aqui, é fundador no sentido da antiga ideia romana da fundatio, ou seja,

[...] da construção da origem e de sua ligação perpétua com o presente, dando-lhe forma e sentido. Mito em duas acepções: na antropológica (solução imaginária de tensões e conflitos que não podem ser resolvidos no real) e na psicanalítica (construção imaginária que recalca os conflitos para poder repeti-los incessantemente sob a forma de sintomas) (CHAUÍ, 1995, p. 78).

Logo, o imaginário social é repleto de crenças que o sustentam e conferem coesão e contextualização internas para que uma determinada civilização se perpetue. A memória coletiva é, dessarte, uma representação comum do passado por toda uma comunidade.

Um direito fundamental, além de uma previsão normativa (aspecto formal), pressupõe uma necessidade protetiva dentro do espaço social em que vigora, pelo que se pode depreender que esses direitos "constituem os principais valores de uma sociedade" (FRANCISCHETTO \& PINHEIRO, 2019, p. 379). Ressalta-se que o rol previsto na Constituição Federal de 1988 nesse tocante não é taxativo, pois novas demandas e prioridades sociais podem surgir com o decurso do tempo.

No entendimento esposado por Dimoulis e Martins (2011, p. 49), os direitos fundamentais têm o desiderato de "limitar o exercício do poder estatal em face da liberdade individual". Com base nesse raciocínio, Francischetto e Pinheiro (2019, p. 380) elaboram que 
a sapiência dos acontecimentos pretéritos de um povo é de suma relevância para a consolidação de sua democracia, visto que as novas gerações necessitam conhecer e reconhecer os arbítrios protagonizados pelo Estado no passado que geraram os mecanismos de contenção de poder no presente, garantindo-se a sobrevivência destes.

Como enfatiza Antonio Leal de Oliveira (2017, p. 14), o esquecimento garante a perpetuação do sofrimento dos oprimidos: ao se obliterar a memória dos que sofreram, há a permanência da opressão por meio de uma violência perene e contínua. Significa dizer, a dor passada precisa ser sentida, necessita ser constantemente lembrada, a fim de que não se repita no presente, gerando um processo de luto, pois há feridas simbólicas que pedem uma cura.

Além disso, “A lembrança não se refere apenas ao tempo: ela também requer tempo um tempo de luto" (RICOEUR, 2007, p. 87). É inegável o papel da memória na resistência à tirania do poder pelas vítimas da história e sua consequente categorização jurídica nos termos de um direito fundamental, portanto.

Partindo-se da constatação de que "consciência e memória são uma única e mesma coisa, independentemente de um suporte substancial” (RICOEUR, 2007, p. 116), tem-se que a formação da consciência do "si" e do "nós" depende da constituição de memória. Assim, “Com ajuda da consciência, é possível apropriar-se de episódios anteriores da vida e integrálos em um self' (ASSMANN, 2011, p. 108).

Ademais, a identidade está em permanente tensão com seu contraponto: a diferença. Desse modo, o que liga os diversos indivíduos à noção de "nós" é "a 'estrutura conectiva' de um saber e uma imagem de si que repousam, por um lado, sob regras e valores comuns e, por outro, sobre a lembrança do passado habitado em comum" (OLIVEIRA, 2017, p. 33). Nesse sentido,

[...] como memória entende-se, primeiramente, um fenômeno puramente interno, localizado no cérebro do indivíduo e que é examinado pela fisiologia cerebral, pela neurologia e psicologia, mas não pela história das civilizações. Entretanto, aquilo que a memória contem, a forma como ela organiza seus conteúdos e o tempo em que pode conservá-los, são temas que dependem, em larga medida, mais dos aspectos externos, ou seja, sociais e culturais, do que da capacidade e do controle interno que possuem (OLIVEIRA, 2017, p. 33).

Embora uma memória de grupo não disponha de qualquer base orgânica, sendo impensável em sentido literal, ela não é meramente metafórica. Por trás da memória coletiva (ou memória cultural), não há alma coletiva ou espírito coletivo; o que há são os signos e símbolos socialmente constituídos, por meio dos quais o indivíduo toma parte da memória comum (ASSMANN, 2011, p. 145). 
É preciso fazer uma separação conceitual entre memória como armazenamento e memória como recordação. O armazenamento pretende conter numa base de dados (seja pela memorização humana, seja por meio de arquivos físicos ou computacionais), uma conexão exata entre o input e o output, isto é, entre o que se depositou e o que se lembrará ou se dirá acerca daquilo em qualquer ocasião em que seja necessário acessa-lo. Já a recordação procede de forma reconstrutiva: ao resgatar as informações contidas, sempre ocorre uma deformação, uma distorção, ou seja, toda vez em que acontece, há uma nova atribuição de valor e de sentido conforme o que se está vivenciando no presente, de modo que aquele evento pretérito é a todo o tempo ressignificado. Nas palavras de Canabarro e Flores (2018, p. 153):

A Memória não é uma reprodução pura e estática [...]. Geralmente ela é o resultado
de uma construção, que com o tempo pode sofrer mudanças, conter omissões,
distorções e simplificações, em face de interesses, sentimentos e experiências da
vida cotidiana [...] Recordação e criação são aspectos presentes no processo de
elaboração da Memória.

Disso decorre que, no intervalo de latência entre uma rememoração e outra, as lembranças não estão guardadas em um repositório seguro - estão invariavelmente sujeitas a um processo de transformação (ASSMANN, 2011, p. 33-34).

Como afirma Aleida Assmann,

Indivíduos e culturas constroem suas memórias interativamente através da comunicação por meio da língua, de imagens e de repetições ritualísticas, e organizam suas memórias com o auxílio de meios de armazenamento externos e práticas culturais. Sem estes não é possível construir uma memória que transponha gerações e épocas - o que significa também que a constituição da memória se modifica juntamente com o estado oscilante de desenvolvimento dessas mídias (2011, p. 24).

Da passagem, apreende-se que, por meio da linguagem, da comunicação interativa, com o uso da língua, das imagens e de repetições ritualísticas, é possível haver uma identidade comum, um espaço abstrato de memória, realizando-se uma rememoração coletiva do passado no presente, de forma que, para se saber o que se é, é preciso lembra-se constantemente do que se foi.

A memória é, por tudo isso, não só o resgate de lembranças do que supostamente aconteceu, nem um mero armazenamento de dados do passado. A memória é construção e afirmação de identidades - identidade individual ou identidade de um povo. Em se tratando de memória coletiva, carrega uma dimensão inexoravelmente política, com deliberações acerca do que lembrar e do que esquecer, sendo que a fronteira entre a lembrança e o esquecimento não é fixa e pode ser realocada consoante as ressignificações no presente dos fatos transcorridos no passado, com capacidade de gerar processos de identificação e 
desidentificação que separem vencedores e vencidos, cidadãos e não-cidadãos. Em síntese, a memória é, acima de tudo, um espaço de disputa pelo poder.

\section{MONUMENTOS COMO LUGAR DE MEMÓRIA}

Para que exista, a memória coletiva precisa estar suportada em mídias, que são protegida por portadores materiais, como monumentos, memoriais, museus e arquivos, tudo guiado por uma política específica de recordação e esquecimento. No que se refere especificamente aos monumentos, tem-se que

Os acontecimentos e feitos realizados em um passado grandioso, porém obscuro, exigem validação por meio de locais e objetos. As relíquias que têm essa função de validação ganham o status de 'monumentos'.

$[\ldots]$

Os monumentos-relíquias têm, assim, a tarefa de conectar o presente real com os acontecimentos dessa antiguidade maravilhosa, agindo como pontes sobre o abismo do esquecimento, citado ocasionalmente por elas (ASSMANN, 2011, p. 60).

Nessa acepção, as pirâmides do Egito e o Coliseu, por exemplo, são belos monumentos representativos da grandeza dos reis do Egito e da república romana. Não obstante, Françoise Choay adverte, além dos monumentos-relíquia, existem os chamados monumentos históricos. Esses não foram inicialmente feitos nem pensados para se tornarem um destino memorial, mas acabaram adquirindo esse papel devido à sua força enquanto locais de testemunho da história. É o caso de prédios antigos que são tombados pelo poder público, por exemplo. Um dos exemplares mais famosos é o campo de concentração de Auschwitz, no sul da Polônia. O maior símbolo do Holocausto, após a Segunda Grande Guerra, converteu-se num lugar de visitação para cidadãos locais e turistas, isto é, espaço de rememoração das atrocidades cometidas pelo Terceiro Reich. Aqui, vale replicar as palavras da autora, de que:

Melhor do que os símbolos abstractos ou imagens realistas, melhor do que fotografias, são os próprios campos de concentração, parte integrante do drama comemorado, com as suas barracas a câmaras de gaz, que se tornaram monumentos (CHOAY, 1999, p. 21).

A partir dessas considerações iniciais, questiona-se: o que são, enfim, monumentos?

A etimologia da palavra dá conta de que o termo advém do latim, monumentum, que é derivado de monere (advertir, recordar). Indo mais a fundo na origem do seu significado, temse que o sentido do termo remete ainda a mausoléu, uma das analogias possíveis a museu. Resgatando a etimologia do termo mausoléu, arremata Cristina Freire que "O sentido de monumento liga-se, portanto, desde sua origem, a uma relação entre morte e maravilhamento, categorias inerentes também ao museus" (1997, p. 94). 
Em Roma, o monumentum tendia a se moldar em dois sentidos, apresentando-se ora enquanto obra comemorativa de arquitetura ou de escultura (arco de triunfo, coluna, troféu, pórtico), ora como acervo funerário (LE GOFF, 1990, p. 536). Dessarte, constata-se que são objetos, desde sua origem, relacionados à estética e à história (FREIRE, 1997. p. 94-95). Na Antiguidade, para se apagar a memória, necessariamente os monumentos deveriam ser destruídos, prática denominada de damnatio memoriae, sobre a qual esclarece Le Goff:

[...] o senado romano, angariado e por vezes dizimado pelos imperadores, encontra uma arma contra a tirania imperial. É a damnatio memoriae, que faz desaparecer o nome do imperador defunto dos documentos de arquivo e das inscrições monumentais. Ao poder pela memória responde a destruição da memória (1990, p. 443).

$\mathrm{Na}$ história da humanidade, não faltam exemplos de dilapidações de monumentos públicos no intuito de apagamento de memórias, como a destruição dos bustos de Lênin por ocasião da queda do regime soviético no final da década de 1980. Importa ressaltar que os monumentos não se tratam de informações neutras na paisagem de uma cidade, mas sim, de objetos de extremo valor afetivo que jazem em locais escolhidos para servirem de exercício à memória viva pelo recurso da emoção (CHOAY, 1999, p. 16). Detém-se aqui, pois, ao conceito de monumento como res publica, significa dizer, "algo, uma coisa, que está em exposição na cidade" (FREIRE, 1997, p. 90).

Logo, os monumentos têm esse desiderato de realizar uma intervenção na memória, intervenção essa que não é axiologicamente neutra. Ele faz uma convocação do passado, porém, não se trata de um passado qualquer: é um passado selecionado, que deve vibrar com as emoções e cores do presente, de maneira que contribua para preservar a identidade de uma comunidade nacional, étnica, religiosa, familiar, ou tribal (CHOAY, 1999, p. 16).

De mais a mais, eles servem para "apaziguar a angústia da morte e da aniquilação", sendo "uma defesa contra o traumatismo da existência, dispositivo de segurança" (CHOAY, 1999, p. 16). Essas peças sagradas de rememoração são combatentes do esquecimento, desafiam a entropia e a ação dissolvente do decorrer dos anos; nos seus diferentes gêneros e formas (túmulo, templo, coluna, arco de triunfo, estela, obelisco, totem), fornecem conforto, sossego e segurança ao garantir as origens e reafirmar de onde se veio (e, com isso, onde se está e para onde se vai) (CHOAY, 1999, p. 16).

Isso não significa que os monumentos não estejam expostos às injúrias do tempo. A desafetação e o desuso podem ocorrer. A escolha pela conservação ou destruição dependerá 
sempre de como aquela comunidade que os rodeia os percebem num determinado espaçotempo, podendo-se chegar até mesmo à derrubada daqueles.

Segundo Cristina Freire, muitos são os motivos que levam os monumentos a serem retirados de seus lugares de origem: "As alterações nas orientações políticas fazem desabar cabeças e derreter bustos que não mais sejam significativos dos valores a serem cultuados”. A peça tem, frise-se, valor ritual bastante evidente, de modo que "a destruição é também um gesto ritual: o reconhecimento negativo de seu valor" (1997, p. 252, grifo nosso).

Ora, se a definição de um grupo social se dá a partir do que é lembrado e do que é esquecido em conjunto, a reformulação da identidade significa reorganização da memória, o que vale tanto para a comunidade quanto para indivíduos. Essa transformação reflete-se numa revisão dos livros de história, na renomeação de prédios públicos e praças e, igualmente, na profanação ou destruição de monumentos.

\section{DOCUMENTOS DA CULTURA, DOCUMENTOS DA BARBÁRIE: O PROBLEMA DA IDENTIFICAÇÃO AFETIVA COM O VENCEDOR}

Em suas teses sobre o conceito de história, Walter Benjamin aborda não apenas o devir histórico enquanto tal, mas carrega uma profunda reflexão crítica dos discursos a respeito da história (ou das histórias), que, por sua vez, são inseparáveis de uma certa práxis (GAGNEBIN, 1987, p. 8-9). Benjamin dedica uma passagem especialmente à memória histórica e aos seus "documentos da cultura". Trata-se da tese VII, a saber:

Ao historiador que quiser reviver uma época, Fustel de Coulanges recomenda banir de sua cabeça tudo o que saiba do curso ulterior da história. Não se poderia caracterizar melhor o procedimento com o qual o materialismo histórico rompeu. $E$ um procedimento de identificação afetiva. Sua origem é a indolência do coração, a acedia, que hesita em apoderar-se da imagem histórica autentica que lampeja fugaz. Para os teólogos da Idade Média ela contava com o fundamento originário da tristeza. [...] A natureza dessa tristeza torna-se mais nítida quando se levanta a questão de saber com quem, afinal, propriamente o historiador do Historicismo se identifica afetivamente? A resposta é, inegavelmente: com o vencedor. Ora, os dominantes de turno são os herdeiros de todos os que, algum dia, venceram. A identificação afetiva com o vencedor ocorre, portanto, sempre, em proveito dos vencedores de turno. Isso diz o suficiente para o materialismo histórico. Todo aquele que, até hoje, obteve a vitória, marcha junto no cortejo de triunfo que conduz os dominantes de hoje [a marcharem] por cima dos que, hoje, jazem por terra. A presa, como sempre de costume, é conduzida no cortejo triunfante. Chamam-na bens culturais. Eles terão de contar, no materialismo histórico, com um observador distanciado, pois o que ele, com seu olhar, abarca como bens culturais atesta, sem exceção, uma proveniência que ele não pode considerar sem horror. Sua existência não se deve somente ao esforço dos grandes gênios, seus criadores, mas, também, à corveia sem nome de seus contemporâneos. Nunca há um documento da cultura que não seja, ao mesmo tempo, um documento da barbárie. E, assim como ele não está 
livre da barbárie, também não o está o processo de sua transmissão, transmissão na qual ele passou de um vencedor a outro. Por isso, o materialista histórico, na medida do possível, se afasta dessa transmissão. Ele considera como sua tarefa escovar a história a contrapelo (LÖWY, 2005, p. 70).

Aqui, o filósofo judeu faz uma dura crítica ao historicismo, isto é, à historiografia burguesa, oriunda da "grande tradição acadêmica de Ranke a Dilthey, que pretenderia revisar o passado através de identificação afetiva do historiador com o seu objeto" (GAGNEBIN, 1987, p. 8-9). A identificação a que se refere é com os vencedores, aqueles que obtiveram êxito sob os cadáveres e escombros de outros.

Explica Reyes Mate que "O que seduz o historiador atual quando olha para o passado é o brilho, o que triunfou. Isto é, temos empatia com o vencedor. Assim reage o homem em geral" (2011, p. 174). Escovar a história a contrapelo significa, pois, "a recusa em se juntar, de uma maneira ou de outra, ao cortejo triunfal que continua, ainda hoje, a marchar sobre aqueles que jazem por terra" (LÖWY, 2005, p. 73). Nesse ponto, sintetiza Reyes Mate: "Nosso presente está construído sobre os vencidos, que são a herança oculta" (2008, p. 23).

Simbolicamente, o cortejo dos vencedores é representado por documentos da cultura, que também se manifestam na forma de monumentos-relíquia. O Arco de Tito, em Roma, por exemplo, estampa a vitória dos romanos contra a sublevação dos Hebreus e, no seu interior, mostra claramente os soldados romanos transportando os espólios capturados no Templo de Jerusalém. Note-se que a civilização é constantemente elevada com fulcro em atos de barbárie enleados em saques, torturas e assassinatos. Por isso, "Os Arcos de Triunfo são um exemplo notável de documentos da cultura que são, ao mesmo tempo, e indissoluvelmente, documentos da barbárie que celebram a guerra e o massacre (LÖWY, 2005, p. 75).

Assim, há uma infinidade de obras de prestígio produzidas pela "corveia sem nome dos oprimidos", como as pirâmides do Egito, construídas por escravos hebreus, e o Palácio da Ópera, erguido no império de Napoleão III pelos operários vencidos em junho de 1848, concluindo-se que "as grandes obras de arte e de civilização [...] somente podem ser feitas à custa dos sofrimentos e da escravidão da multidão" (LÖWY, 2005, p. 75). Quando não se está representando patentemente esse sofrimento (como no Arco de Tito), ele encontra-se contido em cada peça, em cada tijolo do todo monumental pelo sangue e o suor dos escravos inominados que o puseram de pé.

Há, ainda, os documentos de cultura que, mesmo não representando fielmente (pela direta representação) ou organicamente (pela construção de mãos subalternas) a opressão que lhes é inerente, são documentos de barbárie. Isso porque, ainda que feitos por artistas 
escultores e figurando sob égide de aparente inofensividade na paisagem urbana, indiretamente, ostentam opressões sociais de classe, gênero, etnia, cor etc, de maneira silenciosa e naturalizada.

Os heróis oficiais têm seus títulos e imagens perpetuados no atravessar dos séculos: seus nomes estão em ruas, praças, cidades, escolas, universidades, departamentos, batalhões, fóruns, tribunais e prédios públicos e particulares em geral. Seus rostos e compleição física jazem eternamente na forma de estátuas, bustos, moedas e medalhas. Frequentemente, homens brancos, ricos, colonizadores e senhores de escravos são o pano de fundo das cidades onde vivem uma grande massa de mulheres, negros, indígenas e pobres. Esses, por sua vez, compõem a margem, são os não-vencedores, os oprimidos; significa dizer: aqueles que "vivem permanentemente em estado de exceção, isto é, privados do direito" (MATE, 2008, p. 26).

A título de exemplo de tais homenagens monumentais aos triunfadores da história, no Brasil, têm-se: em Goiânia e São Paulo, respectivamente, as estátuas dos bandeirantes Bartolomeu Bueno da Silva e Manuel de Borba Gato, que saquearam aldeias, escravizaram e mataram indígenas; a estátua em homenagem ao ditador Emílio Garrastazu Médici, em Cuiabá; também em São Paulo, encontra-se o monumento ao Coronel Luís Alves de Lima e Silva (Duque de Caxias), figura imperialista e escravocrata designada como Presidente e Comandante das Armas da Província para conter a revolta da Balaiada (1838-1841), no Maranhão, liderada por escravos e trabalhadoresb(ARTE QUE ACONTECE, acesso em: 20 ago. 2020).

Essas são apenas algumas amostras. Não só no Brasil, mas no mundo inteiro, estão espalhadas imensuráveis homenagens a torturadores, saqueadores, escravizadores e assassinos. Na perspectiva de Benjamin, é preciso opor-se a essa tradição, que é um instrumento das classes dominantes. É preciso escovar a história cultural a contrapelo, isto é, “considerá-la do ponto de vista dos vencidos, dos excluídos, dos párias” (LÖWY, 2005, p. 79).

Há que se negar veementemente qualquer identificação afetiva com o agressor. Igualmente, é preciso resistir e lembrar da dor daqueles que sofreram no passado. Lembrar de uma maneira não apenas apreciativa, mas transformar o luto em luta, fazendo valer as vidas que foram interrompidas e o sangue que fora derramado. 
Absolutamente necessário, pois, lembrar do que "não" aconteceu, perscrutar na lata de lixo dos eventos a não-notícia, o não-fato. Lembrar, aqui, é exercitar a empatia por aqueles que padeceram, a fim de jamais permitir que a aflição pretérita caia no obscuro apagamento da indignidade história, relegada a um não-lugar referencial. A bússola do passado a se utilizar na construção do presente deve ser exatamente essa: a dos que lutaram e perderam, dos que foram escravizados e não tiveram voz, dos torturados e esquecidos, a multidão sem nome que subsiste no subsolo fático; jamais a do agressor, do colonizador, daquele que, imbuído por um sentimento de superioridade, escravizou, estuprou, matou, enfim, impôs-se pela bruta força.

Nesse prisma, para o poeta da realidade Walter Benjamin, é imprescindível vasculhar os vestígios utópicos secretos contidos no cerne da história e das obras de cultura tradicionais. O historiador benjaminiano é aquele que revolve o que ficou para trás no assoalho pelo qual passou a marcha vencedora, "resgatando dessa enorme reserva de dejetos possibilidades latentes de redenção" (MATE, 2011, p. 185). Afinal, profetiza Eduardo Galeano (2019, p. 25), "A pobreza não está escrita nas estrelas, o subdesenvolvimento não é fruto de um obscuro desígnio de Deus" e "A ordem é a diuturna humilhação das maiorias, mas sempre é uma ordem - a tranquilidade de que a injustiça siga sendo injusta e a fome faminta". É exatamente contra essa ordem de coisas que é preciso levantar-se incansavelmente, na perspectiva de Benjamin.

Nessa batalha contra os fatos instituídos, há uma tensão permanente entre a preservação do patrimônio cultural e o seu momento destruidor: "somente quebrando a concha reificada da cultura oficial, os oprimidos poderão tomar posse desse molusco crítico/utópico", na leitura de Michael Löwy (2005, p. 80). Essa destruição já ocorreu e ocorre de forma literal ao longo do curso da humanidade. Além do que fora feito com os já mencionados bustos de Lênin no fim da Guerra Fria, conta-se que, em 1992, uma multidão de indígenas, sob o comando dos zapatistas do Exército Zapatista de Libertação Nacional (EZLN), assolou a escultura do conquistador espanhol Diego de Mazariega, no centro de San Cristobal de las Casas, capital de Chiapas, no México (LÖWY, 2005, p. 79).

Noutro contexto, em 2003, na conjuntura da Guerra ao Iraque, a estátua do ditador Saddam Hussem foi levada ao chão por uma multidão local enfurecida, com o auxílio de soldados americanos (BBCBRASIL, acesso em: 21 ago. 2020). Mais recentemente, em junho de 2020, a figura do confederado Jefferson Davis foi abatida em Richmond, na Virgínia, nos 
Estados Unidos (CAFÉ HISTÓRIA, acesso em: 21 ago. 2020), bem como, em ocasião mais marcante, houve a derrubada da estátua do escravocrata britânico Edward Colston, em Bristol, na Inglaterra (G1, acesso em: 20 ago. 2020). Ambos os episódios supra deram-se no contexto de protestos antirracistas que se espalharam em diversos locais do globo após a brutal morte do cidadão afro-americano George Floyd, cruelmente sufocado por um policial de Minneapolis em 25 de maio do mesmo ano. A ação foi gravada e suas imagens rapidamente disseminaram-se pelo mundo, causando amplo horror e indignação.

Evento mais atual ainda, em julho de 2021, manifestantes jogaram pneus e líquido inflamável formando um incêndio ao redor da imensa estátua de 13 metros em homenagem ao bandeirante Manuel de Borba Gato na cidade de São Paulo (EL PAÍS, acesso em: 20 set. 2021). A partir do materialismo histórico benjaminiano, passa-se à interpretação desse fenômeno.

\section{DESTRUIR PARA NÃO ESQUECER: BORBA GATO E AS LIÇÕES QUE VÊM DAS CHAMAS}

Como dito, a memória não é um repositório de lembranças incólume guardado em um local seguro. A normalização do absurdo que ocorrera no passado já não é plausível hoje. Nessa lógica, é preciso revisitar os espaços de poder, os locais de memória, de modo que, às vezes, é necessário derrubar (ou queimar) estátuas.

A economia da região do Estado de São Paulo - à época, capitania de São Vicente sofreu duras baixas em virtude da decadência dos canaviais durante o Período Colonial. Tal situação estimulou expedições pelo interior do Brasil conhecidas como bandeiras e entradas. Nesse sentido, John Manuel Monteiro destaca que a famosa expedição de Raposo Tavares é emblemática da expansão seiscentista na América portuguesa (1994, p. 7). No entanto, ressalta que essa e tantas outras empreitadas de captura oriundas de São Paulo pouco tinham a ver com a expansão territorial. Muito pelo contrário:

[...] ao invés de contribuírem diretamente para a ocupação do interior pelo colonizador, as incursões paulistas - bem como as tropas de resgate da região amazônica e os 'descimentos' dos missionários em ambas as regiões - concorreram antes para a devastação de inúmeros povos nativos (MONTEIRO, 1994, p. 7-8).

De modo que "a ação destes 'colonizadores' foi, na realidade, tragicamente despovoadora" (MONTEIRO, 1994, p. 8). Na época, esses paulistas ficaram conhecidos na América e na Europa como grandes sertanistas, sem iguais no seu conhecimento dos dilatados sertões, na sua perseverança e coragem. Posteriormente, alguns historiadores elevaram-lhes a 
proporções épicas, batizando-os de bandeirantes, em ato de reconhecimento a seu suposto papel na expansão geográfica da América portuguesa.

Não obstante, por trás das façanhas desses heróis intrépidos, esconde-se a história dos milhares de índios aprisionados pelos sertanistas de São Paulo. Grande parte dos estudos tem se concentrado nas peripécias bandeirantes, relegando-se o ciclo de caça ao índio a uma fase preliminar e de importância menor, pela qual os paulistas desbravadores teriam fornecido escravos índios para os engenhos do Nordeste açucareiro, narrativa essa que não necessariamente corresponde à inteireza dos fatos (MONTEIRO, 1994, p. 8). Para Lúcia Lippi Oliveira (1998, p. 104), um dos desdobramentos do mito do sertão é o do bandeirante enquanto responsável pelo aumento do espaço territorial da colônia portuguesa nos séculos XVII e XVIII, de maneira que "O movimento das bandeiras constitui a principal experiência de fronteira na história brasileira".

Dentro do movimento bandeirante, insere-se Manuel de Borba Gato (1649-1718). De acordo com Francisco de Assis Carvalho Franco (1954, p. 176), essa figura histórica, filho de João de Borba e Sebastiana Rodrigues, tratou-se de "paulista de alto mérito, extraordinário desbravador de sertões, descobridor de minas e hábil administrador nos primeiros anos das Minas Gerais". Genro de Fernão Dias, passou a explorar o interior do país, promovendo saques, estupros e diversas violências. Faleceu em 1718, com cerca de noventa anos de idade, quando exercia o cargo de juiz ordinário da Vila do Sabará.

Fato é que existe toda uma mitologia fundacional paulistana em torno do símbolo Borba Gato. Manuel de Borba Gato, símbolo da glorificação dos bandeirantes, juntamente ao Monumento às Bandeiras e o Palácio das Bandeirantes, foi pensado na ocasião do IV Centenário de São Paulo, nos anos 50, quando o Estado queria se posicionar como o principal motor da economia do Brasil, em substituição ao Rio de Janeiro. Nessa esteira, confirma o historiador Bruno Sanches Baronetti, trata-se de um projeto de um passado que restaura as bandeiras e "traz para a historiografia a imagem dos paulistas como um povo que esteve à frente de seu tempo e lutou pelo progresso no Brasil". De fato, os bandeirantes tiveram o mérito de achar ouro, porém isso esconde outras questões, como a escravização de indígenas (EL PAÍS, acesso em: 20 set. 2021). Dessa feita,

Os mamelucos caçadores de índios e de negros pelo sertão brasileiro foram o símbolo escolhido por uma cidade que queria se mostrar rica, afeita a desafios e cujo principal valor norteador seria o 'trabalho' (BARONETTI, 2021, p. 254). 
É nesse plano de fundo forjado pelo historicismo brasileiro que paira a composição mítica em torno da efígie em questão, imersa, hoje, em profundas divisões no debate memorial da cidade. Essa disputa chegou ao auge no acontecido em julho de 2021, ocasião em que a estátua de Borba Gato foi atacada em uma ação política engendrada por militantes antirracistas e da periferia.

$\mathrm{O}$ ato, que consistiu na colocação de pneus envoltos em líquido inflamável em torno da estátua por manifestantes, com lançamento de fogo ao final, foi marcado pela imagem das chamas e da fumaça escura que rapidamente tomaram toda a compleição do monumento. A autoria do ataque ao desbravador-escravocrata foi assumida por Paulo Galo Lima, fundador do movimento Entregadores Antifascistas, que se apresentou voluntariamente à delegacia, sendo preso em seguida. Os responsáveis pelo incêndio fazem parte do movimento Revolução Periférica. Antes de se apresentar às autoridades policiais, o líder da causa declarou a jornalistas:

O ato no Borba Gato foi para abrir um debate, não para machucar alguém ou causar pânico na sociedade. E o debate foi aberto. As pessoas agora podem decidir se querem uma estátua de treze metros de altura que homenageia um genocida estuprador de mulheres (EL PAÍS, acesso em: 20 set. 2021).

Alguns argumentam que destruir ou retirar as estátuas e outros objetos de memória é apagar a história ou, até mesmo, atentar contra a cultura daquela sociedade em que se está inserido. Por outro lado, é possível concluir que, como ensina Walter Benjamin, é chegada a hora de contar a história a contrapelo, ou seja, sob a perspectiva dos vencidos. Isso porque os esquecidos acabam por morrer duas vezes, em vida e já mortos, pois diante do esquecimento das suas mortes, da reificação dos seus corpos, tornam-se meros números.

Escovar a contrapelo é, pois, nadar contra a corrente histórica, conferindo rostos e nomes a esses corpos-número e, mais do que isso, trazê-los à vida a partir da redenção. Significa dizer: fazer valer seu sofrimento passado no presente, lutando contra a estrutura de violência e arbitrariedade de que foram vítimas. Nos fragmentos preparatórios das suas famosas teses, Benjamin afirma que é muito mais difícil honrar a história dos sem-nome do que aquela das pessoas reconhecidas e notórias. Em face disso, é especialmente em memória dos sem nome que deve ser dedicada a reconstrução da história (BENJAMIN, 2012, p. 175).

Nesse aspecto, a mensagem política benjaminiana traz a ideia de que ele não está preocupado apenas em recuperar uma tradição. Sua preocupação consiste em dar voz aos excluídos; é rememorar suas histórias, ouvir a sua narração sobre o que lhes acometeu, de forma a possibilitar a criação de uma nova tradição. Significa que é negando a continuidade 
dos fatos e buscando o que foi interrompido, esquecido, camuflado, que ele pretende uma nova versão da história capaz de restabelecer a responsabilidade com o mundo e com o outro. Essa responsabilidade vem do que se deve aos antepassados, cujo presente foi construído pelas suas lutas.

Enquanto lugares de memória e de homenagem, estátuas foram e precisam ser destruídas, porque elas são símbolos, espaços de poder e de identificação. Com todo o acúmulo de lutas e de reflexões, nos dias de hoje, enaltecer a desumanização pela escravização, o genocídio e o estupro é da ordem do inaceitável.

Construir e manter o trabalho de memória depende de se reconhecer que, diferentemente do registro histórico do passado, a memória exige um contínuo trabalho no presente para se manter viva. Pode-se afirmar que a memória é a história viva, é a história ainda presente, ainda doendo, aberta a novas escrituras.

É notório, no Brasil, que ainda é incipiente o desenvolvimento de uma teoria da memória que dê conta de suas próprias feridas, sobretudo quanto aos deletérios efeitos da empresa colonial escravagista e seu corolário no vigente racismo da sociedade brasileira. Há que se referir, nesse sentido, ao passado faltante, não contado, ao passado dos oprimidos, dos derrotados que até hoje anseiam por justiça e pela interrupção do seu sofrimento, sobretudo em um contexto em que o passado dos vencedores segue presente, sob a forma de história oficial, decantada, reproduzida acriticamente e institucionalizada.

Ora, se características físicas - e, mais do que elas, as representações que se constroem a partir do que se categoriza por raça - definem, separam, segregam e matam seres humanos, a memória apresenta-se como ação. Contar e não esquecer o passado dos vencidos não se confunde com reação, porque não se trata de revanchismo, e sim, do conceito benjaminiano de redenção, consistente em, a partir do (re)conhecimento do passado, dos fatos ocultos e insólitos que precederam, transformando o luto em luta, é dizer, reagir ativamente no presente.

Isso porque o racismo de hoje é consequência de uma construção fundada na ojeriza à diferença, ao que não é branco. É exatamente esse contexto que permitiu ações de extermínio como as de Borba Gato, no qual "os sujeitos eram percebidos de acordo com os elementos físicos e morais da raça a qual pertenciam" (PIRES, 2013, p. 32), o que ainda é causa de dor e trauma em pretos e pretas no Brasil. 
Talvez tenha, enfim, chegado a hora do acerto de contas o passado para que possam ser definitivamente encaradas e superadas as opressões do presente. Logo, importante a afirmação da memória como alternativa viável à sua superação. Ainda, na crítica à historiografia - que não contempla a todos - reside a alternativa de narrar a memória dos vencidos como meio de evitar a repetição do passado trágico, que contém em si a ruptura com a crença no progresso como indutor de benesses.

Fazer esse acerto de contas com o passado é reconhecer, nas palavras de Sérgio D. J. Pena (20008, p.3), que "as raças ainda existem como construções sociais", de modo que o preconceito racial, uma construção, é passível de ser desconstruído. Em verdade, não há povo ou raça que tenha nascido escravo. A escravidão foi invenção do homem subjugando outros às suas vontades e poder, por intermédio da opressão e da restrição da liberdade. É uma triste história, marca indelével da humanidade que precisa ser contada e trazer alguma sensação de redenção. Resgatando seu passado, os vencidos poderão saborear a sensação de ter sua história contada, de se sentirem no centro da história, de finalmente gozarem a redenção. Isso põe em xeque toda uma tradição, que se dedica a contar a história sob a ótica dos vencedores.

Sob essa perspectiva, iluminar o passado trágico exaltado pela homenagem à Borba Gato é forma de redimir os longos anos de submissão imposta pelo tipo que o bandeirante representa. Não em vão, o sistema de justiça penal (branco, conservador e patriarcal) agiu rapidamente e determinou a prisão de um grupo que tentou causar dano - muito mais simbólico que real - no enorme monumento de concreto.

De tudo isso, conclui-se, escovar a história a contrapelo, tarefa mandamental do historiador materialista, é contá-la pelo olhar daqueles que foram sistematicamente pisoteados pela marcha triunfal dos vencedores. Algo fundamental para que as sociedades contemporâneas repensem o que se chama de progresso e modernidade, conceitos brancoeuropeus, e, principalmente, sobre os ossos de quem ocorreu sua pavimentação, às custas de muito sangue, suor e silenciamento. Nesse território de lutas políticas que é a memória, estátuas serão construída e outras serão profanadas. Não como forma de se esquecer o que se viveu, mas como meio de se lembrar daqueles que padeceram para que outros ostentassem seus nomes e seus rostos nas ruas e praças que compõem o estruturado e estruturante imaginário urbano cultural.

\section{CONSIDERAÇÕES FINAIS}


Os monumentos são um tipo de manifestação da memória coletiva e não se tratam de informações neutras na paisagem: são objetos escolhidos, de extremo valor afetivo, que jazem em locais selecionados para servirem de exercício à memória viva pelo recurso da emoção. A escolha pela conservação ou destruição é uma deliberação política e dependerá sempre de como aquela comunidade que os rodeia os percebem num determinado átimo.

Os heróis oficiais têm seus títulos e imagens perpetuados no atravessar dos séculos, com homenagens diversas que os eternizam, sendo uma delas a construção de estátuas em forma de monumentos-relíquia. Não obstante, no ensinamento de Walter Benjamin, é preciso lembrar do que "não" aconteceu, perscrutar na lata de lixo dos eventos a não-notícia, o nãofato e os não-heróis, isto é, exercitar a empatia pela massa dos derrotados da história. Nessa batalha contra os fatos instituídos, há uma tensão permanente entre a preservação do patrimônio cultural e o seu momento destruidor.

Vem do Brasil o exemplo privilegiado da disputa pela memória no presente. No entorno da imagem de Borba Gato e do que ele representa - sobretudo no que carrega de simbólico - travou-se recente batalha: de um lado, revolucionários pretos que em ação previamente organizada atearam fogo em pneus na base da estátua, causando danos físicos pífios, mas resultados políticos importantes. Em oposição ao ato, conservadores disputaram a estátua, por afeição ao que a imagem construída do bandeirante representa ainda hoje, em nome de uma propalada "defesa da história de São Paulo", como declarou um expoente do neoconservadorismo paulistano. No que acabou por conceder razão ao que defende Benjamin e foi exposto no texto.

Enfim, na lição de Benjamin, escovar a história a contrapelo é conta-la pelo olhar daqueles que foram massacrados pela marcha triunfal dos vencedores, repensando o que se chama hoje de progresso e de modernidade (conceitos branco-europeus), e, principalmente, sobre os ossos de quem ocorreu sua pavimentação. Ouvir as vozes silenciadas que ecoam sob os escombros da modernidade, nesse âmbito, é admitir que vidas negras, indígenas e de mulheres importam e que, na constância de uma (re)lembrança coletiva, nunca mais deixarão de importar.

No que pertine à luta pela afirmação e constituição da identidade preta, mormente sob o jugo de uma sociedade que insiste em se manter sob uma lógica colonial, a abordagem racial da memória se apresenta como alternativa pertinente a ser trazida para o debate, na academia, mas não só, pois, para que atue enquanto indutora de afirmação da identidade, é 
fundamental que se dê também sob a perspectiva individual. Logo, se derrubar a estátua de Borba Gato é uma demanda coletiva, identificar-se com Zumbi dos Palmares auxilia na construção da individualidade do sujeito marginalizado e esquecido.

Destruir estátuas, nesse contexto, nada mais é que legítimo exercício de lembrançaesquecimento, um movimento pulsante que manifesta a viva memória, a disputa política pelo espaço no jogo entre o claro e o escuro rememorativo, transgressão à ordem transgressora que se revela não num vazio direito ao apagamento, mas no direito de lembrar daqueles que sempre foram esquecidos, que se consubstancia, também, no direito de não homenagear genocidas, escravocratas, torturadores e estupradores.

\section{REFERÊNCIAS}

ARTE QUE ACONTECE. 10 estátuas pelo Brasil que poderiam ser retiradas. Disponível

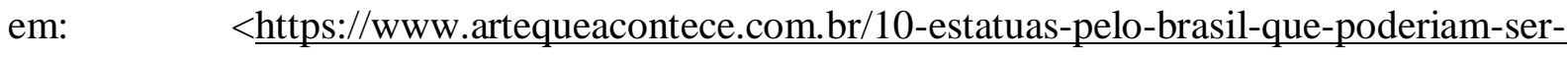
retiradas/>. 2020. Acesso em: 20 ago. 2020.

ASSMANN, Aleida. Espaços da recordação: formas e transformações da memória cultural. Tradução: Paulo Soethe. Campinas, SP: Editora da Unicamp, 2011.

BARONETTI, Bruno Sanches. Espaços de sociabilidade das populações negras em São Paulo: as escolas de samba e suas intersecções com os movimentos associativos (1949-1978). 2021. 466 f. Tese (Doutorado) - Faculdade de Filosofia, Letras e Ciências Humanas da Universidade de São Paulo.

BBCBRASIL. Multidão ajuda a destruir estátua de Saddam Hussein. Disponível em: < https://www.bbc.com/portuguese/noticias/2003/030409 estatuaaw.shtml>. 2003. Acesso em: 21 ago. 2020.

BENJAMIN, Walter. Eduard Fuchs, colecionador e historiador. In: BENJAMIN, Walter. O anjo da história. Tradução: João Barrento. Belo Horizonte: Autêntica Editora, 2012, p. 123164.

BENJAMIN, Walter. Magia e técnica, arte e política: ensaios sobre literatura e história da cultura. Obras escolhidas, vol. 1. Tradução de Sérgio Paulo Rouanet. 3. ed. São Paulo: Editora Brasiliense, 1987, p. 165-196.

CAFÉ HISTÓRIA. Especialistas comentam derrubadas de monumentos e estátuas pelo mundo. Disponível em: <https://www.cafehistoria.com.br/especialistas-comentamderrubada-de-estatuas-pelo-mundo/> . 2020. Acesso em: 21 ago. 2020. 
CANABARRO, Ivo dos Santos. FlORES, Luís Gustavo Gomes. Direitos humanos, transformações sociais e a reconstrução da memória sobre a ditadura brasileira: reflexões a partir da comissão nacional da verdade. Revista de Direitos e Garantias Fundamentais, Vitória, v. 19, n. 2, p. 149-180, maio/ago. 2018.

CARVALHO FRANCO, Francisco de Assis. Dicionário de Bandeirantes e Sertanistas do Brasil: séculos XVI - XVII - XVIII. São Paulo: Comissão do IV Centenário da Cidade de São Paulo, 1954.

CHOAY, Françoise. A alegoria do patrimônio. Revisão e tradução: Pedro Bernardo. Lisboa: Edições 70, 1999.

DANTAS, Fabiana Santos. O direito fundamental à memória. 2008. 285 f. Tese (Doutorado em Direito Constitucional) - Centro de Ciências Jurídicas, Universidade Federal de Pernambuco, Recife.

EL PAÍS. Prisão de ativista que queimou Borba Gato provoca debate sobre a memória de São Paulo. Disponível em: https://brasil.elpais.com/brasil/2021-07-29/prisao-de-ativistaque-queimou-borba-gato-provoca-debate-sobre-a-memoria-de-sao-paulo.html. Acesso em: 20 set. 2021.

FRANCISCHETTO, Gilsilene Passon P.; PINHEIRO, Priscila. Para que não se esqueça: direito fundamental à memória e a contribuição da formação escolar. Joaçaba, v. 20, n. 2, p. 377-396, jul./dez. 2019.

G1. Manifestantes derrubam estátua do traficante de escravos Edward Colston em Bristol, na Inglaterra. Disponível em: <https://g1.globo.com/mundo/noticia/2020/06/07/manifestantes-derrubam-estatua-do-

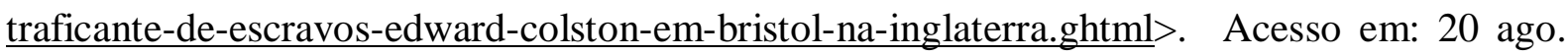
2020.

GALEANO, Eduardo. As veias abertas da América Latina. Tradução: Sergio Faraco. Porto Alegre, RS: L\&PM, 2019.

LE GOFF, Jacques. História e memória. Tradução: Bernardo Leitão. Campinas, SP: Editora da Unicamp, 1990.

LÖWY, Michael. Walter Benjamin: aviso de incêndio: uma leitura das teses "Sobre o conceito de história". São Paulo: Boitempo, 2005.

MATE, Reyes. La herencia del olvido: ensayos en torno a la razón compasiva. Madrid: Errata Naturae, 2008. 
MATE, Reyes. Meia-noite na história: comentários às teses de Walter Benjamin "Sobre o conceito de história". Tradução de Nélio Schneider. São Leopoldo, RS: Ed. UNISINOS, 2011.

MONTEIRO, John Manuel. Negros da Terra. Índios e Bandeirantes nas origens de São Paulo. São Paulo: Companhia das Letras, 1994.

OLIVEIRA, Antonio Leal de. O direito à memória como um dos fundamentos da dignidade humana: memória política e a justiça para as vítimas do progresso. 2017. $312 \mathrm{f}$. Tese (Doutorado em Direito) - Programa de Pós-Graduação em Direito, Pontifícia Universidade Católica do Rio de Janeiro, Rio de Janeiro.

Oliveira, Lúcia Lippi. A conquista do espaço: sertão e fronteira no pensamento brasileiro. História, Ciências, Saúde-Manguinhos [online]. 1998, v. 5, pp. 195-215.

PENA. Sérgio D. J. Humanidade Sem Raças?. São Paulo: Publifolha, 2008.

PIRES, Thula Rafaela de Oliveira. Criminalização do racismo: entre política de reconhecimento e meio de legitimação do controle social dos não reconhecidos. 2013. $323 \mathrm{f}$. Tese (Doutorado em Direito) - Programa de Pós-Graduação em Direito, Pontifícia Universidade Católica do Rio de Janeiro, Rio de Janeiro.

RICOEUR, Paul. A memória, a história, o esquecimento. Tradução: Alain François. Campinas, SP: Editora da Unicamp, 2007.

ROUSSO, Henry. A memória não é mais o que era. In: AMADO, Janaína; FERREIRA, Marieta de Moraes (Orgs.). Usos e abusos da história oral. 8a. ed. Rio de Janeiro: Ed. FGV, 2006, p. 93-101. 